\title{
AFROPOLITAN NARRATIVES AND EMPATHY: MIGRANT IDENTITIES IN CHIMAMANDA NGOZI ADICHIE'S AMERICANAH AND SEFI ATTA'S A BIT OF DIFFERENCE
}

\author{
DOBROTA PUCHEROVA
}

\begin{abstract}
The article analyzes two novels of migration by Nigerian women authors in the context of Afropolitanism: Chimamanda Ngozi Adichie's Americanah (2013) and Sefi Atta's A Bit of Difference (2013). It is argued that Afropolitanism obscures the reasons why migration from Africa to the West has been increasing in the decades since independence, rather than decreasing. In comparing the two novels, the article focuses on empathy towards and solidarity between fellow Nigerians, which has been seen by Nigerian philosopher Chielozona Eze as crucial for building African civil society and functional state.
\end{abstract}

Key words: Afropolitanism; empathy; Nigerian women writers; Nigerian expatriate writers; Chimamanda Ngozi Adichie; Sefi Atta

\section{Introduction: Definitions of Afropolitanism}

"Afropolitanism" was coined by the writer Taiye Selasi in her article "Bye Bye Babar" from 2005. Born in 1979 in London of a Nigerian mother and a Ghanaian father, Selasi studied American Studies at Yale, International Relations at Oxford and resides in Rome. She considers herself a "local of Accra, Berlin, New York and Rome" (Selasi, 2015), that is, an Afropolitan:

They (read: we) are Afropolitans - the newest generation of African emigrants, coming soon or collected already at a law firm/chem lab/jazz lounge near you. You'll know us by our funny blend of London fashion, New York jargon, African ethics, and academic successes. Some of us are ethnic mixes, e.g. Ghanaian and Canadian, Nigerian and Swiss; others merely cultural mutts: American accent, European affect, African ethos. Most of us are multilingual: in addition to English and a Romantic or two, we understand some indigenous tongue and speak a few urban vernaculars. There is at least one place on The African Continent to which we tie our sense of self: be it a nation-state (Ethiopia), a city (Ibadan), or an auntie's kitchen. Then there's the G8 city or two (or three) that we know like the backs of our hands, and the various institutions that know us for our famed focus. We are Afropolitans: not citizens, but Africans of the world. (Selasi, 2005) 
Selasi's definition is remarkable for its focus on modernity, success, sophistication and worldliness - as if set out to destroy all negative images of Africa. Hers, she suggests, is the new, promising African generation: born of highly skilled Africans who left Africa in the 1960s and 1970s for the West. Once deeply confused adolescents having to "forge a sense of self from wildly disparate sources" (Selasi, 2005), these Africans are today, argues Selasi, at the forefront of trying to understand and complicate Africa: "Perhaps what most typifies the Afropolitan consciousness is the refusal to oversimplify; the effort to understand what is ailing in Africa alongside the desire to honor what is wonderful, unique" (Selasi, 2005).

On the other hand, Afropolitanism has been theorized by the Cameroonian cultural critic Achille Mbembe as an ethical position of being open to others by the virtue of occupying several cultural spaces. He arrived at the term after his scholarly investigations of South Africa in transition using cosmopolitan Johannesburg (where he is based) as his case in point. As Mbembe explained in an interview, "Afropolitanism refers to a way-the many ways - in which Africans, or people of African origin, understand themselves as being part of the world rather than being apart" since "historically, Africa has been defined in the Hegelian paradigm as out of history, as not belonging to the world" (Balakrishnan, 2016, p. 29). He emphasizes Afropolitanism as an identity based not on exclusion or opposition but on being through others or relation; an identity whose allegiance is to the worldwide human community:

the awareness of this imbrication of here and elsewhere, the presence of the elsewhere in the here and vice versa, this relativization of roots and primary belongings and a way of embracing, fully cognizant of origins, the foreign, the strange and the distant, this capacity to recognize oneself in the face of another and to value the traces of the distant within the proximate, to domesticate the unfamiliar, to work with all manner of contradictions-it is this cultural sensibility, historical and aesthetic, that suggests the term Afropolitanism. (Mbembe, 2006, p.11, trans. by Skinner, 2017, p. 10) ${ }^{1}$

Unlike Selasi, Mbembe does not speak primarily of the privileged travelling classes, but of Africans based in African urban centres. This is because urban cultures are those that are most open to foreign influences, but also because, as Mbembe explains in an earlier article, it is in the urban centres where the lack of a coherent national culture is most felt. As a result, an African urbanite "mobilizes not just a single 'identity', but several fluid identities, which, by their nature, must be constantly revised" (Mbembe, 1992, p. 5, cited in Skinner, 2017, p. 11). What is most distinguishing about Mbembe's definition is its focus on empathy: "a way of embracing $[\ldots]$ the foreign, the strange and the distant, this capacity to recognize oneself in the face of another" (see above). The Levinasian face calls attention to Mbembe's ethical focus in thinking about African identities.

\footnotetext{
1 "La conscience de cette imbrication de l'ici et de l'ailleurs, la présence de l'ailleurs dans l'ici et viceversa, cette relativisation des racines et des appartenances primaires et cette manière d'embrasser, en toute connaissance de cause, l'étrange, l'étranger et le lointain, cette capacité de reconnaître sa face dans le visage de l'étranger et de valoriser les traces du lointain dans le proche, de domestiquer l'infamilier, de travailler avec ce qui a tout 1 'air des contraires - c'est cette sensibilité culturelle, historique et esthétique qu "indique bien le terme Afropilitanisme."
} 
The Nigerian, US-based scholar Chielozona Eze describes the term very similarly to Mbembe, although, like Selasi, he speaks of those Africans who, like him, are at home in the world's metropoles: "Their spatial mobility informs their inner mobility and their readiness to negotiate reality. ... I identify them as Afropolitans because they lay claim to Africa and the world in a flexible gesture of unbounded humanity" (Eze, 2015, p. 115). Physical and mental mobility are thus interrelated: Afropolitans believe that

being African is not reductive to color, heritage or autochthony; rather, being African is expansive. ... We are not half this and half that; we are this and that. We are Igbo and Yoruba and Efik and Xhosa; we are black and white and brown. We are home in Enugu, Lagos, Johannesburg, Bayreuth, Nairobi or Chicago. We are fitted not just with double consciousness; we possess multiple-consciousness, for we perceive the world from multiple perspectives. (Eze, 2015, p. 117)

This anti-essentialist embracing of cultural, racial and hybridity, very similar to Thabo Mbeki's famous 1996 speech "I am an African" made on the occasion of the passing of the new democratic Constitution of South Africa, is for Eze a precondition of "empathic imagination", which he defines as "the idea of switching perspectives with others; it is the challenge to see the world from the other person's standpoint without any traces of superiority or a position of power or privilege that could be detected in pity" (Eze, 2014, p. 243).

Despite the great humanist potential of this anti-nativist definition that rejects identitarian politics, the term Afropolitanism has also received criticism. In his plenary lecture entitled "I am a Pan-Africanist, not an Afropolitan" at the 2012 ASAUK conference, Kenyan writer Binyawanga Wainaina argued that Afropolitanism was a phenomenon that was increasingly "product driven", "design-focused", and potentially "funded by the West". Stephanie Bosch Santana concurs: "To see Wainaina's point, one needed only to look at the way magazines, designers, and business executives had seized the term for their own purposes" (Santana, 2016, p. 121). She recognises that "style, in and of itself, is not really the issue" but fears rather that it's "the attempt to begin with style, and then infuse it with substantive political consciousness that is problematic" (Santana, 2016, p. 121). Similarly, in her article "Why I am (still) not an Afropolitan", Emma Dabiri, who describes herself as an "Irish/Nigerian woman", criticizes Afropolitanism for its "collusion with consumerism" and its "blindness to class and cultural hierarchies": it is said to be the lifestyle of the privileged few and seems to measure African progress "by the extent to which Africa can reproduce Western lifestyle" (Dabiri, 2016, pp. 104-106). According to Dabiri, while Afropolitanism may appear to offer an alternative to the single story of Africa presented in Western media, we run the danger of this becoming the dominant narrative for African success:

The traditional Afro-pessimistic narratives, while obsessed with poverty, denied the poor any voice. While Afropolitanism may go some way in redressing the balance concerning Africans speaking for themselves, the problem lies in the fact that we still don't hear the narratives of Africans who are not privileged. (Dabiri, 2016, pp. 105-106)

Here, Dabiri is making an important point about how Afropolitanism obscures the ways in which Africans travel to the West: a few of them with visas on international flights, but 
most of them on unsafe boats, crossing the Mediterranean without papers, or flying with fake identities, victims of people traffickers. The narratives of Afropolitanism focus on the first group of migrants. Even though there has been an increasing stream of life narratives of the second category of migrants, ${ }^{2}$ these stories of modern-day slavery, child soldiers and refugees do not by definition represent Afropolitanism, since they show how Africa, in many ways, remains "out of history, as not belonging to the world" (Balakrishnan, 2016, p. 29); they also show how the West is often unwelcoming to these victims, who are seen as being from another world and cultures incompatible with the West (see Helff, 2009).

It is this privilege of being from a moneyed class and having the ability to travel overseas which the Nigerian writer Yewande Omotoso, based in South Africa, sees implicated in the term Afropolitanism. She says she is not an Afropolitan, because even though she has travelled, she does not "identify with the West" but feels herself to be an African:

Many of those Africans who travel and get educated overseas have the money and the means to do that. So they are of a privileged class, that's all. ... The term Afropolitan only seems useful for the West as it gives the West an opportunity to understand and even 'consume' Africa. [...] It is interesting that all these books are coming up now - Adichie's Americanah, NoViolet Bulawayo's We Need New Names (2013), Teju Cole's Open City (2011), Selasi's Ghana Must Go and so on - because they are all about identity, the traveller, the African living in the West. (Fasselt, 2015, p. 235)

\section{The Afropolitan narratives}

Omotoso's point that Afropolitan narratives are intended for consumption is worth thinking about. Consumption is normally associated with popular literature written primarily for entertainment. None of the so-called Afropolitan novels mentioned by Yewande Omotoso belongs to this category - all of them have been marketed as serious novels, primarily for Western audiences. They remain barely known in Africa, as seen, for instance, in the scarcity of reviews given to these novels in the African media. They are the sort of novel that has come to represent African literature in the West: written in English by an expatriate African author who resides and publishes in the West, they describe the negotiation of African identity in the West from the perspective of a middle-class, Western-educated African. Moreover, they use Western plots and narrative forms even when parts of these novels are set in Africa. Omotoso suggests that these novels appeal to Western audiences or to Africans living in the West precisely because they are easy to understand-no effort is required to decode their symbolic systems. In other words, they do not require the ability to "embrac[e], fully cognizant of origins, the foreign, the strange and the distant" as Mbembe writes (see above).

The narrative of the African travelling to the West is typical of the African anti-colonial and postcolonial Bildungsroman. It includes classics such as Cheikh Hamidou Kane's

\footnotetext{
2 See e.g., Desert Flower (1998) by Waris Dirie, Infidel (2006) by Ayaan Hirsi Ali, Escape from Slavery (2003) by Francis Bok, Slave, The True Story of a Girl's Lost Childhood and Her Fight for Survival (2004) by Mende Nazer, A Long Way Gone (2007) by Ishmael Beah, or the novels On Black Sister's Street (2009) by Chika Unigwe and Harare North (2009) by Brian Chikwava.
} 
L'Aventure ambiguë (Ambiguous Adventure, 1961), Chinua Achebe's No Longer at Ease (1960), and Camara Laye's Dramouss (1966). What makes the Afropolitan novel different from these earlier works is that Africa and the West are no longer seen in stark binary opposition to each other. Instead, they are perceived as part of one world, complementary rather than in irreconcilable cultural conflict, operating with the same or similar references, worldviews and values. The protagonist is typically a young, high-achieving African professional with a Western education, or aspirations for a Western education, who moves fluidly between the West and Africa and fits almost seamlessly into both. These novels include-apart from the ones mentioned above-for example Biyi Bandele's The Street (1999), Leila Aboulela's Minaret (2005), Segun Afolabi's Goodbye Lucille (2008), Sefi Atta's A Bit of Difference (2013), Imbolo Mbue's Behold the Dreamers (2016), Tendai Huchu's The Maestro, The Magistrate \& The Mathematician (2014) or Zukiswa Wanner's London - Cape Town - Joburg (2014). Similarly, we can also identify the genre of the Afropolitan short story, such as Sefi Atta's "A Temporary Position" (2009), Doreen Baingana's "Questions of Home” (2005), or Chinelo Okparanta's "America” (2013).

While the term Afropolitanism has the political potential to overcome the ontological Africa vs. the West binary, it could be argued that this idea was already present in the term postcolonial, which sought to emphasize the cultural hybridity brought about by colonialism. More problematically, the celebratory optimism of Afropolitanism blurs the reasons why migration from Africa to the West has been increasing in the decades since independence, rather than decreasing. By focusing on the process of integration into Western society, the underlying causes of why Africans leave Africa (related to state failure) often remain underanalyzed in the so-called Afropolitan novel. Moreover, as already mentioned, the term is also problematic because it refers only to the educated middle-class Africans, being silent about the masses of poor, illiterate and paperless migrants.

To illustrate my claim, I will compare two novels of migration by two Nigerian female authors: Chimamanda Ngozi Adichie's Americanah and Sefi Atta's A Bit of Difference. Both novels were published in 2013 in the USA. The authors are very similar, of middleclass backgrounds, possess a Western university education and are globally mobile, living alternately in the USA and Nigeria. Their protagonists are also very similar: after earning educational credentials and professional experience in the West, they return to Nigeria and try to readjust themselves to the Nigerian reality that in many ways fails to meet their new desires and lifestyles. However, while Adichie does not analyze the reasons why Nigerians migrate to the West and portrays travelling to the West as a natural path taken by those Nigerians who seek happiness, Atta devotes a lot of analysis to this and views it as a problem. The novels have been extensively discussed in the American, Canadian, British and even South African press but not in the Nigerian press, which shows that the Afropolitan novel seems to lack relevance for Africa-based audiences and the two worlds do not quite overlap as the theorists of Afropolitanism would wish.

\section{Chimamanda Ngozi Adichie, Americanah (2013)}

Chimamanda Ngozi Adichie has been called an Afropolitan by Selasi and others (see Pahl, 2016), a term that she rejects: 
I am tired of this word. I am African. [...] [H]istory (sadly not well known) shows that cosmopolitanism doesn't date from yesterday: many African kings from the West coast sent their children to study in Europe. And much later, the generation of my father travelled a lot, there have been numerous waves of people coming back in the 1960's, and who have not stopped moving. They define themselves as Africans. (Santana, 2016, p. 122)

It is undeniable that Africans have tended to travel, especially in the postcolonial period. However, as becomes clear in her novel, rather than a simple wanderlust, quest for education or the desire to know other cultures, Africans are driven to the West for socio-economic and political reasons that make it impossible for them to attain happiness at home. This includes civil wars and terrorism, lack of access to clean water and electricity, an inability to complete university, find a sustainable job, feel safe, or simply have choices. As her character Obinze meditates, he left Nigeria even though he was not starving because he could not bear "the oppressive lethargy of choicelessness" and was "hungry for choice and certainty", "conditioned from birth to look somewhere else, eternally convinced that real lives happened in that somewhere else" (Adichie, 2013, p. 341). Obinze goes to Britain on a visitor's visa, overstays and is deported with other Nigerians who knew "they would come back and do it over again because they had nothing to lose" (Adichie, 2013, p. 347). The other main character, Ifemelu, goes to the United States to complete her graduate degree because she is unable to do it in Nigeria due to university teacher strikes.

How does migration to the West affect Adichie's Nigerian characters? Does it make them capable of embracing the foreign other, as Mbembe writes, or able to see the world from the other person's perspective, as Eze expresses it? Does it complicate their African identity (Selasi)? Problematically, many "been-tos" or expatriates uncritically accept Western culture as superior and the knowledge of its symbolic system becomes a sign of high social status:

Fred mentioned Stravinsky and Strauss, Vermeer and Van Dyck, making unnecessary references, quoting too often, his spirit attuned across the Atlantic, too transparent in his performance, too eager to show how much he knew of the Western world. [...] He was [...] the sort of man who did a good American accent and a good British accent, who knew [...] how to make foreigners comfortable and get foreign grants for dubious projects. (p. 505)

This passage suggests that if Afropolitanism means becoming culturally Western, then clearly there is nothing revolutionary or even interesting about it. The novel parodies Nigerians who have acquired Western accents and manners of expression, such as Doris, who ends every sentence with a question mark and is enthusiastic about "networking" with other expatriates in the "Nigerpolitan Club" with whom she shares experience, values and a worldview (p. 499).

However, even as the novel parodies the Nigerian "been-tos" who become a distinct class of people, estranged from other Nigerians, it never represents the Nigerian poor and focuses exclusively on the careers and love problems of its middle-class protagonists, Obinze and Ifemelu, from whose point of view it is narrated. Even though their desires to improve their lives are legitimate, I must agree here with Emma Dabiri, who writes:

The problem is not that Afropolitans are privileged per se-rather it is that at a time when poverty remains endemic for millions, the narratives of a privileged few telling us how great 
everything is $[\ldots]$ may drown out the voices of a majority who remain denied basic life chances. (2016, pp. 105-106)

The poorest of Nigeria-street sellers, beggars, street children, ubiquitous in city streets - are mentioned in the novel only once in passing, even though the last part takes place in Lagos. This is when Ifemelu returns to Lagos after thirteen years in the United States:

\begin{abstract}
Lagos assaulted her; the sun-dazed haste, the yellow buses full of squashed limbs, the sweating hawkers racing after cars $[\ldots]$ and the heaps of rubbish that rose on the roadsides like a taunt. [...] One morning, a man's body lay on Awolowo Road. [...] [S]he had the dizzying sensation of falling, falling into the new person she had become, falling into the strange familiar. Had it always been like this or had it changed so much in her absence? [...] Ifemelu stared out of the window, half listening, thinking how unpretty Lagos was, roads infested with potholes, houses springing up unplanned like weeds (Adichie, 2013, pp. 475, 477).
\end{abstract}

Here Ifemelu experiences the reality of Lagos as both "strange and familiar": its uncanny quality surfaces, having been repressed in her memory when living in the USA. She continues to repress it, riding in an air-conditioned car between her air-conditioned office and her air-conditioned home that insulates her from the grim outside world. Given that this is the only glimpse of the Nigerian underclass in the novel, the reader never learns why Nigeria is unable to offer its citizens meaningful choices or what causes the enormous social inequality and chaotic infrastructure. The narrative assumes the reader already knows this and takes it for granted that a Nigerian seeking a better life will naturally want to leave the country. Even though both characters eventually return to Nigeria, this is seen as involuntary (in Obinze's case) or a compromise (in Ifemelu's case); they never become open to the other, less fortunate Nigerians or even recognize their plight. The restricted narrative point of view focuses on their private struggles to readjust to Nigeria, where Ifemelu misses "low-fat soy milk, NPR, fast internet [and] good customer service" (p. 502) and Obinze feels his marriage is merely "floating-along contentment" (p. 588) rather than true happiness. There is no "capacity to recognize oneself in the face of another" (Mbembe, 2006, p. 11), this time not the "foreign", "distant" other but the intimate otherthe fellow Nigerian, the neighbour. This lack of empathy for the fellow African is what Chielozona Eze (2011) identifies as being at the root of dysfunctional African societies. This is because Africans tend to "explain the African condition by some innocuous reference to colonialism, and thereby dodging [...] responsibility to their societies" (p. ix). His question, "Can Africans ever empathize with fellow Africans?" (p. xiii), brings me to the analysis of the second novel.

\title{
Sefi Atta, A Bit of Difference (2013)
}

The novel's protagonist is Deola Bello, an independent Nigerian woman whose behavior runs against traditional Nigerian values. At 39, Deola is happily single. The holder of a British passport, she lives in London and works for an international charity. She sees herself as a "Nigerian expatriate in London" (Atta, 2013, p. 11) and likes living there, even though she refers to Nigeria as home. As someone who went to a British boarding school, had 
summer camps in Switzerland, then studied at the London School of Economics, Deola is, like Ifemelu, the epitome of Afropolitanism: a high-achieving, successful, cosmopolitan African woman who knows the "ways of the world".

Admittedly, living in multicultural London and travelling a lot has made Deola much more tolerant than the average Nigerian: her friends include church-going Nigerians but also secular white feminists and gay Nigerian men. One of the reasons why she prefers living in London are Nigerian conservative and patriarchal attitudes; the other is the dysfunctional Nigerian infrastructure and services. In this sense, Deola's Afropolitanism is more of a lifestyle choice rather than an ethical attitude. To emphasize how "unhomed" she is, the narrative shows how on a visit home, Deola prefers to stay in a hotel with uninterrupted electricity and internet access, rather than at her parents' house.

The novel does not celebrate Afropolitanism; instead, it constantly thematizes Deola's alienation and unsettledness. While Adichie's Americanah focuses on Western racism and prejudice towards Africans, Atta's novel is much more focused on Nigerian society and the reasons why those who can, leave the country:

How had Nigeria governed itself after independence? Two failed attempts at civilian governments, a four-year civil war and God knows how many military regimes in between. [...] All we have is oil money circulating in our economy. The whole banking sector is running on laundered money. The whole of Nigeria is. (Atta, 2013, pp. 55, 73)

The novel is very critical not only of Nigerian corruption at the highest level, but also of the general lack of social consciousness and empathy towards other fellow citizens. Nigeria is described as a deeply unequal society, and migration to the West as deepening these class divides. Expatriates with a British education who "speak phonetics" (p. 171) see themselves as the elite of the nation, or "oyinbo", which in Nigerian Pidgin means "white", while the uneducated Nigerians are called "bush". Such education-based class hierarchies reflect what Deola calls "colonial hangovers" (p. 171). She offers a very precise opinion on why Nigerians cannot create a functioning society-because there is no solidarity among citizens:

Nigerians are as prejudiced as the English, and more snobbish. Nigerians, given any excuse, are ready to snub. Without provocation and even remorse. They snub one another, snub other Africans, other blacks and other races. Nigerians would snub aliens if they encountered them. [...] Nigerians constantly rank each other according to health, education and formation, with ambiguous results: this one is bush, that one is oyinbo. (pp. 43, 99)

This is why, Deola explains, charity in Africa is difficult with aid often being squandered: "I don't see Africans helping each other that much either. [...] That is why charities annoy us so much. We don't care about each other" (p. 129). When comparing British and Nigerian immigration policies, she is quick to point out that Nigerians have no compassion for other Africans or even other Nigerians:

Nigerians made beggars out of child refugees from Niger and impregnated their mothers. Nigerians kicked out Ghanaians when Ghanaians became too efficient, taking over jobs Nigerians couldn't do, and named a laundry bag after the mass exodus: the Ghana Must Go bag. Nigerians aren't even sorry about the civil war. They are still blaming that on the British. (p. 16) 
As the quotes above show, Deola's experience of living in multicultural London and being exposed to many people very different from her, whom she learns to tolerate and even befriends, makes her capable of recognizing the lack of solidarity among Africans and the plight of others, such as the Ghanaians and refugees from Niger. Yet, Deola observes Africa's troubles only from afar and is not interested in a closer view, even though she works for an international charity: "She has seen it before and it is the same whenever she watches the news. Expecting more would be like asking her to bury her head into a pile of dirt and willingly take a deep breath in" (p. 14). This shows that Deola, just like Ifemelu in Americanah, remains willingly locked in her middle-class "bubble". Even though Deola does not go far enough towards what Eze calls "empathic imagination", her ability to at least think about less fortunate people makes the novel much more Afropolitan in Mbembe's sense, or, to use Eze's word, a novel with a "multiple consciousness".

\section{Conclusion}

It is impossible to speak about Afropolitanism without mentioning the literary field, the monopoly of literary legitimacy, and the cultural capital, terms coined by the French sociologist Pierre Bourdieu, which are key to understanding the way African literature is produced, marketed and consumed, as Graham Huggan (2001), Wendy Griswold (2000), Sarah Brouillette (2007) and others have shown. It is now taken for granted that the publishing of African literature is concentrated in London, New York and Paris; authors published by African publishers have a smaller readership, fewer chances of winning literary prizes or being recognized by literary critics and scholars. This has to do with what Bourdieu calls "the monopoly of literary legitimacy, i.e., inter alia, the monopoly of the power to say with authority who are authorized to call themselves writers" (Bourdieu, 1993, p. 42). It is a monopoly that belongs to those who possess cultural capital, which, says Bourdieu, is always unevenly distributed because it circulates within a symbolic economy of cultural value that is configured in a series of interlocking hierarchical structures. Since cultural capital is concentrated in the West, African writers gain recognition in Africa (and the world) only after gaining credentials there. This is also why the majority of internationallyknown African writers happen to live in Europe or the United States: it gives them better opportunities to network, be visible and become familiar with the tastes and preferences of the reading public.

The Kenyan writer Binyavanga Wainaina, the 2002 winner of the Caine Prize for African Writing, has spoken about how this British prize consecrated him as a writer and literally changed his life:

Until I won the Caine Prize nobody in Kenya was interested in the fact that I wrote fiction, except my friends. Nobody cared. Of course, being an ex-colonial country, when you win something from abroad they regard you more. [ ... ] It is a shame on our country to get foreign legitimacy before one's work could be appreciated. [...] Maybe it's neo-colonialism I don't know. But that's how it works. (Umaisha, 2008)

The recognition provided by the Caine Prize (given for a short story, typically to a beginning writer) was instrumental in bringing Wainaina the offer of the prestigious post of 
director of the Chinua Achebe Center at Bard College in New York. After several years of his "Afropolitan" experience, Wainaina quit his job and decided to return to Kenya. In answer to what he thought of Afropolitanism, he responded:

It's this kind of identity... which... bears no responsibility. It consumes, sometimes it creates, but it has no residence in any solid value. You know... it's a fashion. [...] I think Achille Mbembe has written about it, and I think the idea was a different idea, actually, than the one that got picked up as a sort of commodity, ja? ... The wrong kind of Afropolitanism gives you immunity [...] You have a Green Card, ok? I don't have a Green Card, but, like, I could get one. Or you have many stamps in your passport, so, when you want to go to Schengen, you can go to Schengen. You become this kind of internationalized class of people who ... call yourself an intellectual ... you are changing continents... But you are completely immune to the reality of the continent. And that immunity, once you have it, it kind of stays, you know. How you see and how you interact is fully infected by that immunity. So you can encounter and have compassion for something happening to somebody who hasn't got immunity, but only with sympathy - like, ooh, you poor people, you know-like that. [...] I came to a point when I said to myself - I have been lying to myself in that Afropolitan way that you can build an African literary institution out of New York. That's a lie. You can't (Solés, 2014, transcript of an audio recording)

Like many critics of Afropolitanism, Wainaina sees Afropolitanism as a "fashion". Moreover, similarly to Sefi Atta's narrator, he is suggesting that Africans living in the west have become cut off from their fellow citizens and immune to Africa's problems, feeling no empathy for those who still live there and capable only of a "sympathy" that "bears no responsibility". As Eze writes, this is not empathy, but "pity", because it is expressed from a position of superiority. By living and working in Kenya, where he founded the literary magazine Kwani?, Wainaina is not only trying to reverse the flow of African writers to the West, but also to remain connected to Africa and its problems, since he feels that without having that experience he cannot possibly reach African readers. As he implies above, for him, the shared experience of writers and readers is the basis for building a reading culture. A discussion of Afropolitanism thus cannot avoid the question of the relevance of expatriate writing for Africa-based readers as well as the issues of empathy and social responsibility, precisely because, as Wainaina, Omotoso and Dabiri suggest, the Afropolitans are a privileged few in comparison to the majority of Africans who are denied basic chances in life.

\section{References}

Adichie, Chimamanda Ngozi. (2013). Americanah. New York: Random House.

Atta, Sefi. (2013). A bit of difference. Northampton, MA: Interlink Books.

Balakrishnan, S. (2016). Pan-African legacies, Afropolitan futures: A conversation with Achille Mbembe. Transition, 120, 28-37.

Bourdieu, P. (1993). The field of cultural production: Essays on art and literature. R. Johnson (Ed.). New York: Columbia UP.

Brouillette, S. (2007). Postcolonial writers in the global literary marketplace. Basingstoke and New York: Palgrave.

Dabiri, E. (2016). Why I am (still) not an Afropolitan. Journal of African Cultural Studies, 28(1), 104108. 
Eze, C. (2011). Postcolonial imagination and moral representations in African literature and culture. Plymouth: Lexington Books.

Eze, C. (2014). Rethinking African culture and identity: The Afropolitan model. Journal of African Cultural Studies, 26(2), 234-247.

Eze, C. (2015). We, Afropolitans. Journal of African Cultural Studies, 28(1), 114-119.

Fasselt, R. (2015). "I'm not Afropolitan - I'm of the Continent": A Conversation with Yewande Omotoso. Journal of Commonwealth Literature, 50(2), 231-246.

Griswold, W. (2000). Bearing witness: Readers, writers and the novel in Nigeria. Princeton: Princeton UP.

Helff, S. (2009). Refugee life narratives: The disturbing potential of a genre and the case of Mende Nazer. In E. Bekers, S. Helff, \& D. Merolla (Eds.), Matatu, 36. Transcultural Modernities: Narrating Africa in Europe (pp. 331-346). Amsterdam-New York: Rodopi.

Huggan, G. (2001). The postcolonial exotic: Marketing the margins. London: Routledge.

Mbembe, A. (1992). The banality of power and the aesthetics of vulgarity in the postcolony. Public Culture, 4(2),1-30.

Mbembe, A. (2006). Afropolitanisme. Africultures, 66(1), 9-14.

Pahl, M. (2016). Afropolitanism as critical consciousness: Chimamanda Ngozi Adichie's and Teju Cole's Internet presence. Journal of African Cultural Studies, 28(1), 73-87.

Santana, S. B. (2016). Exorcizing the future: Afropolitanism's spectral origins. Journal of African Cultural Studies, 28(1), 120-126.

Selasi, T. (2005). Bye Bye Babar. The LIP Magazine, March 3. Retrieved June 5, 2018, from http:// thelip.robertsharp.co.uk/?p=76

Selasi, T. (2015). Don't ask where I'm from, ask where I'm a local. TED speech, Sept. 29. Retrieved June 5, 2018, from https://www.ted.com/talks/taiye_selasi_don_t_ask_where_i_m_from_ask_ where_i_m_a_local/transcript?language=en

Skinner, R. T. (2017). Why Afropolitanism matters. Africa Today, 64(2), 2-21.

Solés, G. (2014). Wainaina on Afropolitanism. April 4. Retrieved June 5, 2018, from https://www. urbanafrica.net/urban-voices/wainaina-afropolitanism/

Umaisha, Sumaila Isah. (2008). Those who don't read fiction don't write well: Interview with Binyavanga Wainaina. New Nigerian Newspapers, Dec. 6, 2008. Retrieved June 5, 2018, from http://everythinliterature.blogspot.com/2010/07/ those-who-dont-read-fiction-dont-write.html

Institute of World Literature,

Slovak Academy of Sciences,

Dúbravská cesta 9,

84104 Bratislava

Slovakia

Email: dobrota.pucherova@gmail.com 